\title{
December 2017
}

\section{True (A) or false (B):}

\section{The Life Esidimeni tragedy: Constitutional oath betrayed}

1. Members of Provincial Executive Councils in South Africa take an Oath of Allegiance to the Constitution when sworn into office.

Life Esidimeni psychiatric patients in Gauteng Province, South Africa: Clinicians' voices and activism - an ongoing, but submerged narrative

2. People with mental illness are seen in low regard because of stigma.

3. A court interdict to prevent patients from being moved out of Life Esidimeni in March 2016 was dismissed.

4. The Gauteng Department of Health did not agree in court that the same level of care as received by patients at Life Esidimeni would be received at the NGOs.

5. Patients with intellectual disability have increased vulnerability because of associated stigma.

\section{The Life Esidimeni tragedy: A human-rights perspective}

6. When individuals do not have decent levels of health, it is very difficult to exercise the fulfilment of human rights

7. International human rights instruments are not significant in the context of mental health.

Informed consent and deafness in South Africa: Guidelines for clinicians and researchers

8. There is a significant history of exploitation and unethical experimentation with deaf people across the centuries.

9. The identity of being Deaf and the experience of being deaf and Deaf seems to transcend other identities, such as ethnicity.

Do doctors attending sexual-offence victims have to notify sexualoffence suspects that their patients who were forced to have unprotected sexual intercourse are HIV-positive? What should doctors do?

10. The common law requires doctors to warn endangered third parties where such persons may suffer injury as a result of interactions with their patients.

11. The doctor-patient relationship is an example of a special relationship.
Transparency in medicines regulatory affairs - reclaiming missed opportunities

12. Transparency is not a value in the South African Constitution.

13. Constitutional rights are not absolute and can be infringed upon.

How do healthcare professionals manage ethical challenges regarding information in healthcare professional/patient clinical interactions? A review of concept- or argument-based articles and case analyses

14. It is always clear how information should be managed within the clinical context.

Public health officials and MECs for health should be held criminally liable for causing the death of cancer patients through their intentional or negligent conduct that results in oncology equipment not working in hospitals

15. Breaching the Public Finance Management Act will not result in criminal liability.

16. Murder is the unlawful and unintentional killing of another human being.

A study of the role and functions of inspectors of anatomy in South Africa

17. Inspectors of anatomy do not monitor the use of human tissue for research purposes.

18. Regulations relating to human tissue banks have not as yet been promulgated in South Africa.

\section{The 2016 CIOMS guidelines and public-health research ethics}

19. Public-health research prioritises health promotion and disease prevention among populations over protection of individuals.

20. Public health research ethics is relatively underdeveloped compared to other health-research ethics.

A maximum of 6 CEUs will be awarded per correctly completed test.

The CPD programme for SAJBL is administered by Medical Practice Consulting.

CPD questionnaires must be completed online at www.mpconsulting.co.za

After submission you can check the answers and print your certificate.

Questions may be answered up to 6 months after publication of each issue.

Accreditation number: MDB015/171/02/2017 (Ethics) 